\title{
ARTIGO
}

DOI: https://doi.org/10.22481/praxis.v15i31.4665

\section{TEACHERS' SUBJECTIVITY IN ENGLISH TEACHING: (AUTO) BIOGRAPHY AND NARRATIVES}

\author{
LA SUBJETIVIDAD DE LOS PROFESORES EN LA ENSEÑANZA DE INGLÉS: (AUTO) \\ BIOGRAFÍA Y LAS NARRATIVAS
}

\begin{abstract}
A SUBJETIVIDADE DOS PROFESSORES NO ENSINO DE INGLÊS: (AUTO) BIOGRAFIA E NARRATIVAS
\end{abstract}

Carla Graciele Ramos Fraga Instituto Federal do Norte de Minas Gerais - Brasil

Denise Aparecida Brito Barreto Universidade Estadual do Sudoeste da Bahia - Brasil

\begin{abstract}
This article aims at presenting data analysis produced during the research conducted at IFNMG in partnership with UESB. English teachers that work in Basic Education, High School Courses integrated with Technical Courses participated in this research. Supported by Autobiographical methodology and narrative interviews, this article presents data that contributes to comprehending English Teaching considering the teachers' subjectivity, which includes their personal stories and experiences of English learning in different contexts. Data has shown that teachers' own learning experiences of the foreign language has a significant impact on their teaching practice and classroom decisions.
\end{abstract}

Key words: English teachers. Learning experiences. Narrative interviews.

Resumen: Este artículo pretende presentar el análisis de datos producidos durante una investigación realizada en el IFNMG en asociación con la UESB. Profesoras de Inglés que trabajan en la Enseñanza Media integrada a los cursos técnicos participaron de la investigación. Utilizando como base la metodología autobiográfica y las entrevistas narrativas este presente trabajo presenta datos que contribuyen a la comprensión de la Enseñanza de Inglés considerando la subjetividad docente, incluyendo sus historias personales y experiencias de aprendizaje del inglés en diferentes contextos. Los datos indican que las experiencias de aprendizaje de la lengua extranjera tienen un impacto significativo en las prácticas educativas y las decisiones en el aula.

Palabras claves: Entrevistas narrativas. Experiencias de aprendizaje. Profesores de inglés. 
Resumo: Este artigo visa apresentar a análise de dados produzidos durante uma pesquisa realizada no IFNMG em parceria com a UESB. Professoras de Inglês que trabalham no Ensino Médio integrado aos cursos técnicos participaram da pesquisa. Ancorada na metodologia autobiográfica e entrevistas narrativas este artigo apresenta dados que contribuem para a compreensão do Ensino de Inglês considerando-se a subjetividade docente, incluindo suas histórias pessoais e experiências de aprendizagem do inglês em diferentes contextos. Os dados indicam que as experiências de aprendizagem da língua estrangeira tem um impacto significativo nas práticas educativas e decisões em sala de aula.

Palavras chaves: Entrevistas narrativas. Experiências de aprendizagem. Professores de Inglês.

\section{Introduction}

Considering that foreign language teachers develop strategies to approach the foreign language (FL), elaborate lesson plans and learning tasks to students based on their career path and their own learning experiences of the FL that had begun still when they were students we believe that the teaching act occurs in a construct which reflects teachers' beliefs, values, and individual life experiences. (RICHARDS; RODGERS, 2001). In this perspective, we believe that teachers could reflect and improve their practice through a careful look at their own foreign language learning and teaching experiences implicated in their life stories. Almeida (2012) points out that previous language learning experiences considerably influence classroom practice, in other words, we think about the objectives and choices of what and how to teach based on our prior experiences.

Following this thought we see teaching in a concept that different types of knowledge are mobilized by teachers to develop their pedagogical practices. (GAUTHIER, 2006; TARDIF, 2011). These "knowledge" coming from different areas are pointed by Gauthier (2006) as a base knowledge involving discipline (subject), Curriculum (program), Science education, pedagogical tradition, experience and the pedagogical action itself. Although Gauthier (2006) mentions the necessity of studies to comprehend the pedagogical action knowledge, e.g., understand how actions from experiential knowledge could be theorized and validated, in this study, our concern was the understanding of the relation established between the subject (individual) and the learned content. Besides, we sought to comprehend how teachers' own learning experiences contribute to developing teaching practices. 
Our focus differs from Shulman (1986) about understanding knowledge content representation in teachers' mind, but it is close to what the author calls pedagogical content knowledge. The pedagogical content knowledge refers to the subject knowledge used for teaching. According to this thought the teachers use approaches based on the criteria they perceive as relevant from their own life experiences.

A study conducted by Instituto de Pesquisas Plano CDE for British Council about English Teaching at Brazilian Public Education in 2015 that involved state and municipal schools showed that "English teaching is little regulated in Brazil and its offer shows few standards". According to the research it is difficult to evaluate the "quality of offer and generate common strategies to improve learning." (BRITISH COUNCIL, 2015, p.37).

We see this lack of standards to English teaching due to the diversity of contexts inside the institutions, as well as, the teachers' own subjectivity that influences English teaching. This way we believe that understanding teachers' learning experiences with the language rescued from courses they had attended and other contexts increase the discussion over the theme. When we listen to the teachers' stories we find aspects regarding language learning, profession learning and everyday life stories that relate to English Teaching choices.

\section{Finding two pathways: (auto)biography and narrative interviews}

The (auto) biography research ${ }^{1}$ makes it possible to the researcher to work with emotions, subjectivities and intuitions as it perceives the phenomenon's study like a process and not a reality of exact and concluded data. (ABRAHÃO, 2003). Subjectivity, as stated by Bueno (2002) is a striking feature of rupture and change in human sciences research as it goes against experimental methods like in exact and biological areas. The two latter value a rational and objective Science. It is in this context of dissatisfaction with classical Science that emerges qualitative research, although it does not discard quantitative methods, it values the construction of methodologies aimed at whole explanations.

Ferrarotti (2010) points to a renewable biographical method in terms of searching to value primary biographical material, that is, autobiographic narratives produced by the interaction of an investigator rather than secondary material, characterized by objective probe. The author exemplifies secondary material as photos, official documents, verbal process,

\footnotetext{
${ }^{1}$ The term autobiographic, also written (auto) biographic in this work, refers to the studies of Nóvoa and Finger (2010) that present (auto) biographical source as a research method and training practice. We considered as (auto) biographical sources the data produced in the narrative interviews. (JOVCHELOVITCH; BAUER, 2002). However, some authors like Bertaux (1981) present observations about difference in meaning of the terms.
} 
letters, newspaper pieces etc. The biographical material of primary nature is seen as a rich production filled with subjectivity of human praxis. We understand individual human práxis like the author presents it: "[...] synthetic activity, total activity of an entire social context. One's life is one's praxis that frames social relations (social structures), restructuring them into psychological structures throughout activities of rupture and reconstruction". (FERRAROTTI, 2010, p.44).

The above considerations lead us to contextualize the methodological possibility of narratives to investigate our object of study. We comprehend the English teachers of IFNMGSalinas as a specific group, characterized by aspects of their own singular life stories and other people's life stories that make part of a social context, in which they present themselves and are presented by the psychological dimension of subjectivity in their actions. The motivation to investigate the English teachers, thus, relies on comprehending them throughout their oral narratives. When we listen to their life stories associated with learning experiences, training courses experiences and teaching practice stories we can establish connections with their FL teaching practice.

Considering the prior mentioned characteristics of autobiographical research and searching for a methodology that could make it possible listening to the teachers' stories and their individual perspectives we have decided to conduct Narrative Interviews, a technique supported by Jovchelovitch e Bauer (2002) to construct data. The narratives were produced at individual meetings and generated productive material to understanding aspects of FL learning, job experiences and English teaching.

Data was analyzed based on the technique of metaphorical Reading in three times as in Souza $(2006$; 2014). This technique of narrative analysis takes into account the reconstruction of narratives in units of theme. Thus, the reconstruction was held through crossing reading considering meaning and significant. The process of textual meaning condensation and grouping of units was based on characteristics of regularity, irregularity and fundamental recurrence of Hermeneutic and Phenomenology. While reading the narratives we have perceived that some elements were very present: recollections on training courses, FL learning experiences from different contexts and teaching experiences. In the next topic we present a deeper discussion over the issue.

\section{Research context and data analysis}

This research was held in a campus of a Federal institution in northern of Minas Gerais; two English Teachers who work in the institution have participated in it. Both 
participants teach English as a foreign language for high school students who also study a technical course integrated .The teachers periodically teach English for specific courses in some majors offered by the institution. The table below shows relevant information about the participants.

\begin{tabular}{|c|c|c|}
\hline Suject & Jane Austen & Charlotte Brontë \\
\hline $\begin{array}{ll}\text { Higher } & \text { Education } \\
\text { Institution } & \end{array}$ & $\begin{array}{l}\text { Universidade Estadual de } \\
\text { Montes Claros (State } \\
\text { University) }\end{array}$ & $\begin{array}{l}\text { Universidade Estadual de Montes } \\
\text { Claros } \\
\text { ( State University) }\end{array}$ \\
\hline Graduation Year & 1991 & 2003 \\
\hline $\begin{array}{l}\text { Main courses in the } \\
\text { career path }\end{array}$ & $\begin{array}{l}\text { - } \text { Major in Portuguese/ } \\
\text { English } \\
\text { - Specialization lato sensu } \\
\text { in English Language } \\
\text { - Masters in Literature } \\
\text { - Studying doctorate in } \\
\text { Applied Linguistics }\end{array}$ & $\begin{array}{l}\text { - Major in Portuguese/ English } \\
\text { - Specialization lato sensu in } \\
\text { Teaching at higher education } \\
\text { - Masters in Literature }\end{array}$ \\
\hline $\begin{array}{l}\text { Teaching Experience } \\
\text { at Foreign Language } \\
\text { Institutes }\end{array}$ & yes & No \\
\hline $\begin{array}{l}\text { Teaching Experience } \\
\text { at private schools }\end{array}$ & 20 years & 1 year \\
\hline $\begin{array}{l}\text { Teaching Experience } \\
\text { at public schools }\end{array}$ & 10 years & 8 years \\
\hline $\begin{array}{l}\text { Teaching experience } \\
\text { at IFNMG }\end{array}$ & 1year & 6 years \\
\hline
\end{tabular}

Questionnaire responded by participants. Ficticious names

Specific Information about the institutions of graduations as well as teaching experiences declared in the table have helped us view the set of narratives, motivations, objectives, beliefs and reflections in a broader perspective to comprehend data. Analyzing the training courses path of the teachers we perceived that both studied in the same institution and attended the same course of Languages English/Portuguese, but at different times. Jane Austen has graduated from college in 1991 whereas Charlotte Brontë in 2003. They both show anguish of an unsatisfactory course:

Charlotte Brontë: Well, it did not respond the expectations of neither Portuguese nor English areas. But I have had good professors and something that has helped a lot was phonetics subject...so the didactics presentation, the pronunciation issue, the graduation helped a lot, but I think it could have offered more, the fact of the course being double languages was not good 
because it has lacked focus, literature we saw very little, it was just to state in the curriculum and we continue. ${ }^{2}$

Jane Austen: [...] I came from a very poor major, a graduation in which despite having good professors, that were competent, they did not see the necessity of being well qualified at the time, I am 45 years old, then, I did the course when I was 16 years old, so you can imagine Unimontes at that time. The professors were not even specialists, there was not a study culture, it was a really poor graduation.

Jane Austen: [...] during graduation we studied basic notions of the English Language, the professor had to teach simple present of verb to be, and it was basically that because most of the students knew nothing and the class was not divided.

The teachers' speeches lead us to perceive aspects regarding some language courses at the university that sometimes do not provide a qualified training. Especially Charlotte Brontë's speech, which relates the poor graduation to the fact it had offered two languages at the same time. In her opinion the course did not correspond to the expectations on neither Portuguese nor English. Jane Austen had given us another perspective once she outlined the poor qualification of the teachers and the variety of students' English level in the same classroom as the reasons for a "bad English teaching". However, both teachers have continued their studies in order to qualify themselves. They attended courses of lato sensu and strictu sensu and other courses to improve their proficiency.

The narratives' fragments remind us of Paiva's words (2003) about graduation courses of Languages that offer two languages at the same time. According to the author it generates a dispute over the amount of time spent with disciplines of Portuguese and the foreign language and even in some courses that offer only the foreign language, there is the excuse of Portuguese being more relevant than the foreign language making it difficult qualifying the future professionals in both languages. It is true, though, that many courses have made an effort to change such reality and it has had positive results. The same public institution referred by the teachers in the research, for instance, has separated the Course, so nowadays separated language courses are offered: Portuguese, Spanish and English. Besides, students are divided into two groups in the initial terms to make it easier the language teaching according to the students' level. We believe this model of graduation is a possible way to improve teaching in the university and as a result improve foreign language teaching at schools since there will be more qualified professionals.

We sadly state, though, that the governmental actions for Education do not seem to have foreign languages as a priority in the Brazilian public schools. In order to exemplify that,

\footnotetext{
22 Data was produced in portuguese and translated into english.
} 
we mention the law 13.415/2017, which established Spanish as a non-mandatory discipline in the curriculum.

\title{
Family relationship
}

Bringing back family memories in the process of career decisions is a constant aspect when we work with autobiographic narratives, partially because when we select our recalls we tend to report things that have touched us, meaningful memories. (LARROSA, 2002). Thus, we have observed that both participants, Jane Austen and Charlotte Brontë, mention their family's position towards their career choices.

\begin{abstract}
Jane Austen: [...] I had never thought of myself as a teacher, in my family there were no teachers, later my sisters made their careers into education, I am the youngest, but they graduated after me, but honestly, I did not have an influence, actually it was even disappointing to my dad having his daughter choose a teaching career, he was not happy. He said: "Oh, but You are going to be a teacher, you have studied in such good schools, you are so studious, you could do a better course", I felt he was a little sad, but he did not impose anything to me.
\end{abstract}

Jane Austen mentions that there was no direct parental influence or orientation to become a teacher; she possibly became an influence to her older sisters, though, because they made their careers into education too. It is interesting to note that in her dad's point of view Jane Austen's choice was disappointing and thought that she could have chosen a better course since she was studious and had studied in good schools.

Such view of teaching profession as a depreciating one make us think of the challenges and problems faced by the professionals. Oliveira e Feldber (2006 apud SCHEIBE, 2010) consider some aspects like low salaries, poor working conditions due to the number of students in the classrooms, crowded classrooms, indiscipline, school violence and pressure for a better teaching performance. This scenario has resulted in high level of teachers quitting the career and little search for teaching courses. (SCHEIBE, 2010). We agree with the author when she says the unsatisfactory working conditions contribute for depreciating the professionals and their careers.

In Charlotte Brontë's fragments become clear her Family's influence to follow a teaching career, especially her grandma and her mother's sayings. She points out that her mother made her do the former course Normal, that is high school education to teach children.

Charlotte Brontë: My story is a little funny, I mean, my mother is the youngest daughter of her parents and my grandma had been at menopause 
period when she had my mom. So, there is a whole tradition of women being teachers, an ancient thought... and I am the youngest daughter so I grew up among this generation of elderly people and there was this tradition that every woman has to be a teacher, that's why I did Normal, at the time, I remember that my mom made me do that course, she would not let me do Cientifico, it seems I was raised to become a teacher (laughs), there was no other option.

Charlotte Brontë's view of being raised to become a teacher relates to the grandma's and mom's speech that used to see teaching career as a female profession. This idea of teaching being related to female gender emerged in the past as Apple (1988) outlines; it has begun from working relations, in a patriarchal society where women should have a part time job in order to have time to take care of the family. Over the years other meanings were connected to the profession, so it has started to be considered an essentially female job and depreciated one. Gauthier (2006) states a conceptual blindness over teaching profession due to ideas that to become a teacher it is necessary to have a gift, talent, good sense, experience and follow one's intuition. In the author's opinion that is a limited perspective that we ought to change because teaching must not be viewed as a profession connected to characteristics of female gender, it rather has to be oriented by specific teaching knowledge and we share the same opinion.

\section{Teachers' recollections}

When it comes to training path in different contexts it is common to associate the learning process with the experience we have with teachers; while we recollect memories of teachers that made part of our lives we are also able to rescue feelings we had at specific situations. It is not unusual to remember not only the teachers themselves, but also, the feelings and emotions we experienced with them. By doing so, we are able to attribute qualities, positive or negative to the experiences depending on the way they had conducted their practices.

In Jane Austen's fragments we realize she sees teachers as fundamental for a significant and effective learning. The participant has presented recollections of teachers that have participated in her English learning process at different contexts: the teacher of regular school in basic education, the high school teachers, the teachers of the language schools and the teachers of her Specialization Course. See the fragments below:

Jane Austen: my experiences are very good, differently from some people that might have had terrible experiences with English. When I was at basic school, English was an optional subject at schools, I guess it started being a 
demanding discipline in the schools after LDB in 1998, it wasn't a demanding discipline until then, but I studied at a private school; it had English from the $7^{\text {th }}$ grade on, nowadays it corresponds to the $8^{\text {th }}$ grade and I remember that I was looking forward to study English, I did not study English at another school at the time; I was 12 years old and I loved my first English classes, I don't recall the teacher's name, but I remember the first classes I was so delighted that I even remember the first lesson, a little of the dialogue when I was 12, I'll read it to you, better saying, repeat because I know it by heart, there was a book, one of first lessons had a robot that said: "I'm not a boy. I'm not a girl. I'm a robot" and I just loved that. The teacher made this communication, she used to ask us to listen and then repeat, individual speaking, she used English directions with us, she used to ask us to say: "I am sorry for being late"; she motivated us a lot to communicate, so they were amazing learning experiences.

Jane Austen: The teacher always asked us to repeat, that we had to try to speak something, but with little emphasis on grammar, that was good.

Jane Austen: At the English school I felt very comfortable because I loved the fact that I really could communicate, I kept waiting for the class's day, there were only two classes per week, I was anxious for the class's day, there they worked with the four abilities, so activities of listening took place and also speaking, we used to speak English all the time, so it was a very good experience, then I changed to another school, to CCAA and finished my course there, I loved it too, I adapted so well to the methodology that I started teaching there.

In the beginning of the fragment Jane Austen expresses a positive feeling towards her English learning experiences. She points out that studying at a private school was an opportunity to study English because at the time the language was only recommended to have in the public schools curriculum, so many of them did not include it. The period mentioned by Jane Austen possibly refers to the same period mentioned by Leffa (1999) in which the law only recommended teaching in basic education for the schools that could offer the language. It is important to see that Jane Austen recalls the teacher's practice who could possibly try to apply Communicative Approach for English teaching. Although she did not use audio materials the teacher encouraged using the language by repetition and emphasizing communication in real life situations.

See some more fragments about memories of her teachers:

Jane Austen: [...] my English teachers, the ones I had ... I think... my experiences were really good, both at the English school and at regular school, basic and High School. At High School something negative that I have to mention is that there was indiscipline, although it was a school that cared for discipline, but the teacher did not have much control, it was the same teacher from first to third grade. So, I believe the gains were not as much as in basic school ... he used to ask us to read a text, translate it and answer questions; many students were just talking most of the time, at the end he just checked and in the other class he would correct the activities, I wanted to avoid this in my classes, classes in which the students did not produce really. 
Jane Austen: [...] I attended my specialization course at 90s, 1999 or 2000 and the course was ministered by professors of UFMG, they came to teach us at UNIMONTES, so we studied a lot of phonetics, phonology, disciplines that I did not have in my teaching course, and we presented assignments in English, something that I did not have in my teaching course, in the English discipline, at the teaching course we studied the basic rules of the language, the teacher had to teach simple present of verb be and it was basically that because most of the students knew nothing at all and the class was not divided, so the specialization in English with professors of UFMG was very important for my training. I knew great professors like Deisy Pina Dutra, Adriana, I still remember these teachers because they were very important to me.

We realize that Jane Austen confirms that her learning experiences with the English language were very good ones due to teachers and professors who made part of her training process. She also mentioned a negative experience she had with the high school teacher who did not have control of the class and it affected the students' production. She even compares it to the previous teacher and states that the high school teacher's practice was more focused on reading and textual comprehension. This teacher probably applied an approach aimed at English for Specific Purposes. Jane Austen said that the professors of Specialization course were very important for her training, especially, when she compares it to her initial training; the course has contributed to knowledge of disciplines she did not previously have in the course like Phonetics and Phonology.

The fragments of Chrlotte Brontë's narrative about her learning experiences with the language blend negative and positive experiences with teachers and professors that made part of her training process. The contexts mentioned by her were limited to the English School and the Initial Teacher Training Course at the University Languages-English/Portuguese.

Charlotte Brontë: At* I had only one teacher, the teacher was very good, his classes were very dynamic, he used to play the guitar, sing and it helped a lot. Unfortunately I did not have much connection with the teacher, I didn't like him, so because of that I missed many classes, but his classes were very dynamic; later I had a private class with another teacher that also worked at this school, she was not my teacher there, but she has helped me a lot, I had one class with her, and I am very shy so she tried to help me speak... even making mistakes, I was really afraid of making mistakes, so her contribution was essential, it was really good because she helped me overcome this fear.

The first memory that Charlotte Brontë chose to report about her teacher was related to his practice, his pedagogical approach with usage of songs and dynamic classes. Songs are recognized as a strategic ally in the learning process since they are able to awake pleasant sensations and at the same time the sonority can contribute for the words to stay in mind (GOBBI, 2001). However, the participant reports that she was not able to create a bound with 
the teacher and that has negatively influenced her learning process; the fact she did not like the teacher made her lose interest and miss classes.

In the same fragment we realize that Charlotte Brontë brings in her speech aspects of her personality. She mentions her shyness, something that could also explain the reason why she says she was afraid of speaking and making mistakes. She also shows a feeling of gratefulness for the teacher who has helped her overcome her difficulty. Although being helped by the teacher, Charlotte Brontë returns to the report of the negative experience with the prior teacher of the course describing it as a trauma she still has to deal with, as we can see in the fragment below:

Charlotte Brontë: Until today I think I bring this trauma that I had with my first English teacher, I was very shy, he did not know how to deal with it, so sometimes he would impose that I had to speak and that is funny because it seems I have created a block when it comes to listening, I don't know, speaking and listening are very connected, so I like to read, I like to write, but when it comes to speaking I have a blocking, I have like to prepare myself; he was an older teacher and I am not sure if I could say that but (laughs and hesitation) but he used to make a pass at the girls, he used to flatter and I did not like his attitude, he created an unnecessary situation. He kept putting in evidence my shyness, that I had to speak, clearly, he did not know how to deal with it and I bring this difficulty until today, when a person speaks I have to pay a lot of attention to the person to be able to understand what he/she is saying, these are the abilities that I have most difficulty with: listening and speaking. Speaking I have improved, I overcame it but listening I have to look at the person speaking to be able to understand him/her well.

In Charlotte Brontë's speech it is quite evident the negative mark her teacher has left in her life and learning process; when she mentions that he used to impose to her the speaking ability and also the anti-ethic attitude towards the female students. Charlotte Brontë mentions that the teacher kept exposing her shyness, and that has had a negative impact on developing her abilities of listening and speaking. She mentions she learned to deal with her difficulty in speaking but she still has a difficulty regarding listening ability. Next fragment probes how a positive teacher's influence can have in the learning process.

Charlotte Brontë: [...] I think that has helped me a lot to overcome the trauma I had with the previous teacher was professor Lucy, she helped me a lot in speaking ability and I think today I like to work a lot with phonetics because of her, as I told you before I am shy I don't speak much but I speak well, with correct pronunciation because of the experience I had with professor Lucy at the university in the Languages major.

The participant explains the positive contribution that the professor had in her learning process once she had difficulties in pronouncing the words. Using knowledge of phonetics, 
the teacher helped her develop a correct pronunciation and overcome her fear of mispronouncing words. She said that she even started enjoying the discipline because of the professor.

Understanding these English learning experiences connected with the teachers' attitude lead us to reflect about teaching practice, especially because our choices of how to approach the language may influence the students either positively or negatively, in other words, we could promote an effective or a traumatic learning.

Moreover, Miccoli (2010, p.205) point out that "any student keeps in memory or in heart the lessons the teacher was able to transmit, not only the subject content". In this perspective, we agree that secondary learning influences our beliefs and decisions of how to act in the classroom context.

\section{Teaching practice experiences}

A well-known author that is highly mentioned when talking about career stages is Huberman (1992). According to this author in the beginning of teaching career, teachers live a phase characterized by survival and discoveries; they deal with feelings of indifference, frustration and instability. This period refers to the first three years. In the fragment that follows we realize that Charlotte Brontë has experienced deception with the teaching career and it has made her abandon it for a while and work in another area.

Charlotte Brontë: Well, to tell you the truth I have worked about five years, six years at public school, I worked two years, I guess, only at a private school, in Janauba, then education has disappointed me and I tried the contest for another area. I worked as a fiscal at DR and during this period I quit teaching.

Then when I... I worked at DR I used to travel a lot, I used to get home late at night... then I used to think of my mom saying that every woman has to be a teacher, actually we can program better our time of teaching with motherhood, when I was at DR I could not see my children going to school, sometimes I just got a chance to pick them up and it disturbed me a lot.

Charlotte Brontë said the reason to go back to education was her mother's influence, she remembered her mom's words about being able to program her schedule with her family duties. Let's now consider Charlotte Brontë's memories of initial teaching practice:

Charlotte Brontë: [...] I worked with basic education, then the dynamics, games, they had a bad base, but they used to interact well when I worked with the games, so this first contact with pedagogical practice I enjoyed a lot 
and I felt that they were eager for the class and that made me prepare a more dynamic class for them.

In this part, the research participant recalls the beginning of her career, when she worked at basic education. She relates that the students' interest motivated her to prepare better classes; she tried to approach the language through developing dynamics and games in order to promote interaction. We realize that, at the time, she did not have available specific material to work with the students; so, most of her approach was on an individual perception of what and how to teach. Charlotte Brontë continues:

Charlotte Brontë: [...] sometimes when we arrive in the classroom we see some students more willing to speak, even making mistakes they try, they are not shy, but there are also the timid ones, and we did not have such support, guidance of how to deal with these situations, then... I worked with those who wanted to speak letting them speak and dealing with them in a more specific way. Those who were afraid to speak I used my phonetics' professor example in order to help them showing phonetics knowledge [...]

While analyzing this fragment we see that Charlotte Brontë has faced, in the initial phase of her career, the same challenge experienced by many other teachers: the period of time where there was a lack of support to English teaching at public schools. She even mentions a lack of orientation, guidance of how to conduct the classes.

In this fragment, an interesting aspect is that Charlotte Brontë gives a description of the different level of the students, some of them being more willing to speak and others more ashamed, timid. Since she also has faced difficulties with shyness and fear of making mistakes in her learning process she used her previous experiences to tackle this problem. She used the knowledge of Phonetics to help them overcome their fear of mispronouncing the words.

Let us consider some of Jane Austen's fragments from now on:

Jane Austen: One of my main worries, actually two, I have always had two concerns: first- I started working at a very young age, I was 20 , I taught at High School, I had students older than me, I remember a specific military school, I used to teach at night, many of the students were policemen who were studying High School, already adults; it was a big challenge for me, so the biggest challenge was discipline. I really wanted to have classroom control, the methodology did not make much difference, so I started thinking: What would my teacher do if he was here? My memories of when I was a student reappeared and even more than the academic knowledge, I started basing my practice on my prior teachers' practice. The reason why I did so it was because they were effective experiences. My classmates had a good behavior and learning happened. So, sometimes when I used to enter a class with lots of indiscipline I thought: what would my teacher do? Would he scream? Would he hit something on the desk to call attention? Would he 
ask the troublemaker student to leave the classroom? So I started to think of possible manners to act based on the memories of my own experience as a student. My second concern that appeared later was methodology, I used to work a lot with grammar, but most of that was useless to them. They knew irregular verbs by heart, the basic list, I used to apply tests on that subject, so I asked them to study from 1 to ten, then from eleven to twenty, and then there was a moment they knew all the verbs in the past and past participle. I was really proud that they knew that but, eventually I started thinking: Does it really make a difference in their knowledge? They know the verbs in the past, but do they know how to apply them? That started to worry me then I decided to look for a more communicative approach. It is tiring because you have to speak a lot, you have to stand the whole time and you need a lot of controlling so I based my practice on my memories and these two concerns: discipline and methodology.

In this fragment we realized Jane Austen's concern about having control of the class, keep discipline and her worry about methodology. When we go back to her narrative about English learning and her school years' memories we come across the fact that she had studied at Marista school, a school known for discipline and organization. Let's see the fragments:

Jane Austen: I was in a classroom with lots of discipline, a religious school, anything wrong you did the Brothers would warn the parents and there would be punishment, I was in a context with plenty of discipline, learning happened.

Jane Austen: I started teaching at public schools of Minas Gerais state. I passed a test to work as a state teacher and then a test to work at municipal schools in Montes Claros and my first job at a private school was Tiradentes Polícia Militar. At this school I learned to teach, I learned how to organize a classroom,...how to make lesson plans, teaching plans, how to organize my work, I stayed there for ten years, then it truly was a school to me and when I started working at public schools I went to schools located in the outskirts of the city, distant Jobs in the city of Montes Claros; it was really tough, there was no structure, no money, students did not value the English language much, I guess they ' $\mathrm{d}$ rather be doing anything else, but studying English so there wasn't a book, there wasn't PNLD yet, it was really difficult, every day I had to come up with something, get copies with my own money, it was so frustrating that I quit both Jobs, first the job of the state and then the municipal one. I kept working at private schools, I could do a better job, I felt much better, I had better structure, more sources, separated classes; one of the schools for instance had contracted another language school to be in charge of classes and they applied their methodology there (it was CCAA). It was a pleasure to work there.

Jane Austen's teaching experiences happened in different contexts. Initially she mentions Tiradentes da Polícia Militar, which is a military school. As she reports, at this school she learned various activities related to teaching. Another context mentioned by the participant was the period of time in which she taught at regular public schools. She described the difficulties and challenges she had to deal with at the time, the lack of structure, 
indiscipline, lack of books and an inferior treatment towards English discipline. Sadly, some of these problems still persist at many public schools due to lack of governmental policies for Language Education. She mentions that she even gave up the career in public schools because it was frustrating. So, she also lived the period described as a phase of deception. This situation is still the reason why many people don't want to follow a teaching career. Jane Austen preferred to continue her career at private schools that offered her better working conditions.

At the end of the narrative the participant mentions as positive the entrance of an English school at the regular private school. However, we believe such actions do not have a positive effect for the professionals who graduate at languages at the university because it might convey the idea that anyone who knows the language well could teach it, and the discipline in the regular curriculum might lose its importance. However, we understand teaching profession as an activity that involves a base knowledge, including initial knowledge acquired at the university at the Language Course. (RAJAGOPALAN, 2011; GAUTHIER, 2006).

In the next fragment Jane Austen shows her pedagogical practice concerning discipline and having control because in her point of view this is an essential request to achieve effective English learning.

Jane Austen: I have always had trainees in my classes and one day their professors from college told me that their students were frequently saying good things about the organization of my classes, actually I thought I was very strict to my students, they even feared me a bit, "the teacher is coming", and everybody ran to class, I'm not sure about how good or bad it was, but I was able to teach, they participated, I used to be happy with the results because they were good ones... Nowadays I am here teaching High School once again, it's been a while that I didn't teach High School, but I am enjoying it, it has been a great challenge, especially with the first grade, they are more immature and more undisciplined, but I guess I enjoy this when I have to put some order (laughs), they are already getting used to me, when I am getting near class they enter the classroom quickly.

It is very clear the importance given by the teacher to have control and discipline in the classroom, meanwhile, she points out her difficulty to find balance in this matter. Jane Austen herself mentions the fear some students have developed and she worries about this situation being either good or bad. This dilemma of classroom control, of imposing oneself as an attempt to achieve discipline and order is a challenge lived by teachers, like Freire (2013) states teaching demands freedom and authority and finding this balance is a challenge. Some teachers tend to become "dictators" in the students' point of view and it might create a bad 
atmosphere, students might become more resistant and undisciplined on one hand. On the other hand, if teachers are too lenient with the students, profligacy might take place and a chaotic situation tends to occur. We believe the best position in this matter is connected with balance as stated by Freire (2013, p.106): "the toughest position, and undoubtedly the most correct one is of the democrat who is coherent with his dream of solidary and equality, where it is not possible authority without freedom and the latter without the former." Next fragment Jane Austen shows once again the contribution of her learning memories to her practice.

Jane Austen: I wanted to avoid this class in which the students do not produce actually, I was worried about that, I have always checked if the students were doing the requested activities, I used to go to every desk and ask: "what are you doing?" "do you have any doubts?" "Can I help you?" My teachers did not do that and I think it is important. Some attitudes of other teachers I have had and I wanted to avoid were to scream, to hit something on the desk or on the board to call the students 'attention, these attitudes I have always avoided because I consider it a lack of respect to the students.

We realize that Jane Austen has used her previous experience as a student to avoid reproducing what she considered to be teachers' negative behaviors, which in her opinion showed lack of respect to the students. In this matter, she mentions methodological aspects like the importance of checking the students' production and specific attitude to call students' attention.

\section{Final considerations}

This article presented a possibility to use (auto) biography with narrative interviews in order to comprehend specific experiences connected to teachers' subjectivity. We could see that much of what teachers plan and decide to use in the classes is indeed connected with teachers' prior individual learning experiences and we believe this understanding, this whole perspective about the other's story contributes for teaching reflection and as a result English teaching improvement, especially at public schools.

We could understand for instance that the teachers base their practice on meaningful experiences to them; both participants showed the influence they have had form their own teachers and professors and also negative experiences they avoid repeating. These situations became clear when Jane Austen specified methodological and behavioral attitude concerning her previous teachers. In Charlotte Brontë's narrative we could perceive she has a special concern in helping those who are timid and shy to speak because she herself faced similar situations and was helped to overcome her difficulties. We hope that this article 
has contributed for reflecting about English teaching, once listening to other professional's story and their learning experiences might make us think about our own experience and how the actions and decisions we make in the classroom are related to our own English learning experiences from different contexts.

However, we believe Reflection must go beyond "getting to know oneself"; we share the same opinion as Zeichner (2008), that directs to a concept of Reflection focused on the whole context, including moral aspects, ethics and the objective of Education. So, we bring back Gauthier (2006) and restate that we understand teaching like a practice of different knowledge being mobilized, including knowledge of our prior learning experiences.

\section{REFERENCES}

ABRAHÃO, M. Memória, narrativas e pesquisa autobiográfica. História da educação, Pelotas, n. 14, set. 2003.

ALMEIDA, R. Teaching of English as a foreign language in the context of Brazilian regular schools: a retrospective and prospective view of policies and practices. Revista Brasileira de Linguística Aplicada, Belo Horizonte, v. 12, n. 2, p. 331-348, 2012.

APPLE, M. Ensino e trabalho feminino: uma análise comparativa da história e da ideologia. Cadernos de Pesquisa, São Paulo, n. 64, p. 14-23, 1988.

BRASIL. Lei ordinária n⿳ $\mathbf{1 3 . 4 1 5}$, de 16 de fevereiro de 2017. Altera as Leis $n^{\circ} \mathrm{s} 9.394$, de 20 de dezembro de 1996, que estabelece as diretrizes e bases da educação nacional, e 11.494, de 20 de junho 2007, que regulamenta o Fundo de Manutenção e Desenvolvimento da Educação Básica e de Valorização dos Profissionais da Educação. Diário Oficial da União. Brasília, DF, 17 fev. 2017.

BRITISH COUNCIL. O ensino do Inglês na Educação Pública Brasileira. Elaborado com exclusividade para o British Council pelo Instituto de Pesquisas Plano CDE, São Paulo, SP, 2015 .

BUENO, B. O método autobiográfico e os estudos com histórias de vida de professores: a questão da subjetividade. Educação e Pesquisa, São Paulo, v. 28, n. 1, p. 11-30, jan./jun. 2002.

FERRAROTTI, F. Sobre a autonomia do método autobiográfico. In: NÓVOA, A.; FINGER, M. (Org.). O método (auto)biográfico e a formação. Natal, RN: EDUFRN; São Paulo: Paulus, 2010.

FREIRE, P. Pedagogia da autonomia. Saberes necessários à prática educativa. Rio de Janeiro: Paz e Terra, 2013. 
GAUTHIER, C.et al. Por uma teoria da pedagogia: as pesquisas contemporâneas sobre o saber docente. Ijuí: [s.n.], 2006.

GOBBI, D. A música enquanto estratégia de aprendizagem no ensino de língua inglesa. Dissertação (Mestrado em Letras) - UFRGS, Porto Alegre, 2001.

HUBERMAN, M. O ciclo de vida profissional dos professores. In: NÓVOA, Antônio (Org.). Vida de professores.Porto: Porto Ed., 1992. p. 31-62.

JOVCHELOVITCH, S.; BAUER, M. Entrevista narrativa. In: BAUER, M. W.; GASKELL, G. (Ed.).Pesquisa qualitativa com texto,imagem e som: um manual prático. Tradução de Pedrinho A. Guareschi. Petrópolis: Vozes, 2002. p. 90-112.

LARROSA, J. Notas sobre a experiência e o saber da experiência. Revista Brasileira de Educação,n. 19, p. 20-28, 2002.

LEFFA. O ensino de línguas estrangeiras no contexto nacional. Contexturas, APLIESP, n. 4, p. 13-24, 1999. Disponível em: 〈http://www.leffa.pro.br/textos/trabalhos/oensle.pdf〉. Acesso em: 24 set. 2015.

MICOLLI, L. Ensino e aprendizagem de inglês: Experiências Desafios e Possibilidades. Campinas: Pontes, 2010.

PAIVA, V. L. M. O. A LDB e a legislação vigente sobre o ensino e a formação do professor de língua inglesa. In: STEVENS, C. M. T; CUNHA, M. J. Caminhos e colheitas: ensino e pesquisa na área de inglês no Brasil. Brasília: UnB, 2003. p. 53-84. Disponível em: <http://www.veramenezes.com/ensino.htm>. Acesso em: 24 set. 2015.

RAJAGOPALAN, K. Vencer barreiras e emergir das adversidades com pleno êxito, sempre com o pé no chão. In: LIMA, D. C. (Org.). Inglês em escolas públicas não funciona? Uma questão, múltiplosolhares. São Paulo: Parábola Editorial, 2011.

RICHARDS, J. C.; RODGERS, T. S. Approaches and methods in language teaching.[s.L.]: Cambridge University Press, 2001.

SCOVEL, T. Learning new languages: a guide to second language acquisition. Canada: [s.n.], 2001.

SHEIBE, L. Valorização e formação dos professores para a educação básica: questões desafiadoras para um novo plano nacional de educação. Educ. Soc., Campinas, v. 31, n. 112, p. 981-1000, jul.-set. 2010.

SHULMAN, L. Those who understand: knowledge growth in teaching. Stanford, 1986.

Disponível em:<http://journals.sagepub.com/doi/pdf/10.3102/0013189X015002004>. Acesso em: 25 set. 2015.

SIQUEIRA, S. O ensino de inglês na escola pública: do professor postiço ao professor mudo, chegando ao professor crítico-reflexivo. In: LIMA, D. C. (Org.). Inglês em escolas públicas não funciona? Uma questão, múltiplos olhares. São Paulo: Parábola Editorial, 2011. 
SOUZA, E.C.de (Org.). Autobiografias, história de vida e formação: pesquisa e ensino. Salvador/Bahia: EDUNEB - EDIPUCRS, 2006.

SOUZA, E.C.de Diálogos cruzados sobre pesquisa (auto)biográfica: análise compreensivainterpretativa e política de sentido. Revista Educação, Santa Maria, v. 39, n. 1, p. 39-50, jan./abr. 2014.

TARDIF, M. Saberes docentes e formação profissional. Rio de Janeiro: Vozes, 2011.

ZEICHNER, K. M. Uma análise crítica sobre a "Reflexão" como conceito estruturante na formação docente.Edu. Soc., Campinas, v.29, n.103, p.535-554, maio/ago 2008. Disponível em: <http://www.cedes.unicamp.br>. Acesso em: 25 set. 2015.

\section{$\underline{\text { SOBRE AS AUTORAS }}$}

\section{Carla Gracielle Ramos Fraga}

Mestre em Educação pela Universidade Estadual do Sudoeste da Bahia (UESB). Possui graduação em Letras Inglês pela Universidade Estadual de Montes Claros (Unimontes), Especialização em Ensino de Língua Inglesa pela Universidade Federal de Minas Gerais (UFMG). Atualmente atua como professora efetiva de Língua Inglesa no Instituto Federal do Norte de Minas Gerais (IFNMG), campus Salinas. E-mail: carla.ramos@ifnmg.edu.br

\section{Denise Aparecida Brito Barreto}

Doutora em Educação pela Universidade Federal da Bahia (UFBA). Pós-doutorado em Educação pela Faculdade de Psicologia e Ciências da Educação em Coimbra. Professora plena da Universidade Estadual do Sudoeste da Bahia, da Licenciatura em Letras Departamento de Estudos Linguísticos e Literários (DELL) e do Programa de Pós-graduação em Educação/PPGEd. Pesquisadora do Grupo de Pesquisa Linguagem e Educação GPLEd/CNPQ/UESB. E-mail: deniseabrito@gmail.com 